v. $13, n .2$

Vitória-ES, Mar.-Apr. 2016

p. $56-81 \quad$ ISSN 1808-2386 DOI: http://dx.doi.org/10.15728/bbr.2016.13.2.3

\title{
The Use of Management Control Systems and Operations Management Techniques
}

\author{
Edelcio Koitiro Nisiyama ${ }^{\dagger}$ \\ Insper Instituto de Ensino e Pesquisa \\ José Carlos Tiomatsu Oyadomari ${ }^{\Omega}$ \\ Chen Yen-Tsang ${ }^{*}$ \\ Neoma Business School \\ Andson Braga de Aguiar ${ }^{ \pm}$ \\ Universidade de São Paulo - USP
}

Universidade Presbiteriana Mackenzie / Insper Instituto de Ensino e Pesquisa

\begin{abstract}
It is well known that both management control systems (MCSs) and operations management $(\mathrm{OM})$ are related to firm performance; however, an integrated study that involves MCS and $\mathrm{OM}$ within the context of firm performance is still lacking. This research aimed to examine the relationships among the use of MCSs and OM techniques and firm performance in the Brazilian auto parts industry. Simons' levers of control framework was used to characterise the uses of MCSs, and OM techniques, such as total quality management (TQM) and continuous improvement programmes, were adopted. The results obtained through the structural equation modelling indicated that the diagnostic use of MCSs is positively associated with the goals of cost reduction. In addition, the interactive use of MCSs is positively associated with the objectives of introducing new products, which is consistent with previous research. Additionally, OM techniques are positively related to cost reduction but have no direct relationship with the introduction of new products.
\end{abstract}

Keywords: Management control system. Operations management techniques. Performance. Diagnostic use. Interactive use.

Received on 05/30/2014; reviewed on 03/26/2015; accepted on 04/27/2015; published on 03/01/2016.

*Author for correspondence:

†. Master of Science in Business Controllership Mackenzie University Accounting from the University of São Paulo

Link: Professor at Insper

Link: Associate Professor at University Mackenzie and Insper Address: Rua da Consolação , 04546-042 - São Paulo 896 - building 60 , Sao Paulo SP - Brazil SP - Brazil - CEP 01302-907.

E- mail

E- mail:

oyadomari@mackenzie.br Phone: (11 ) 2114-82973 Fax: ( 11) 21148816

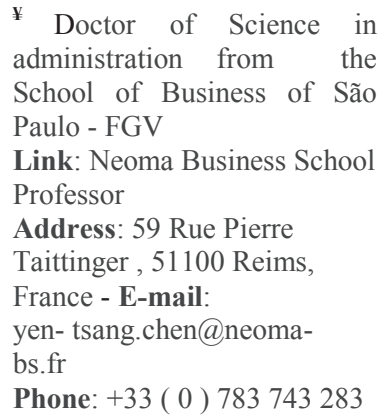
administration from the School of Business of São Paulo - FGV Link: Neoma Business School Professor Address: 59 Rue Pierre Taittinger, 51100 Reims, France - E-mail: yen- tsang.chen@neomabs.fr

Phone: +33 ( 0 ) 783743283

\author{
+ Doctor of Science in \\ Accounting from the \\ University of São Paulo Link \\ : Associate Professor \\ University of São Paulo \\ Address: Rua Prof. Luciano \\ Gualberto, 908, FEA 3 , \\ University City, São Paulo - \\ SP - Brazil - CEP 05508-010 \\ E-mail: abraga@usp.br \\ Phone: (11) 30915820 Fax: \\ (11) 30915822
}




\section{INTRODUCTION}

$\mathrm{n}$ the framework developed by Simons $(1995,2000)$, the use of MCSs is classified as diagnostic use and interactive use. This approach has been used to analyse the effects of MCSs and their relationships with organisational competences (AGBEJULE, 2011; BISBE; OTLEY, 2004; WIDENER, 2007; FERREIRA; OTLEY, 2006; HENRI, 2006a). For example, Henri (2006a) presented the first research with the dimension of

use, including both interactive and diagnostic use, grounded on the resource-based view (RBV) through an examination of the relationships of the use of an MCS with organisational capabilities and performance.

Previous studies have reported dissonant results, both in the studies of the use of MCSs (HENRI, 2006a; BISBE; OTLEY, 2004) and in the studies of OM techniques, such as quality programmes (CORREDOR; GONII, 2011; CUA; MCKONE; SCHROEDER, 2001; O'REAGAN; SIMS; GHOBADIAN, 2004; REED; LEMAK; MERO, 2000). Such differences suggest the need for new empirical research involving MCSs and OM techniques. The auto parts industry in Brazil is particularly interesting because of its global environment and because it is formed by firms of various sizes in a highly competitive context. The automotive industry chain as a whole is characterised by constant innovations and cost reduction programmes, which constitute a favourable environment for our research.

Beyond MCSs, it is also well known from the OM literature that companies can achieve sustainable competitive advantages through their operations (FERDOWS; DE MEYER, 1990; FLYNN; FLYNN, 2004; WHEELWRIGHT; HAYES, 1985; WHEELWRIGHT, 1984). According to $\mathrm{OM}$ researchers, operations must assume a strategic importance within companies (FERDOWS; DE MEYER, 1990; SKINNER, 1969; WHEELWRIGHT, 1984).

More recently, several studies have demonstrated the positive influence of operations on company performance (PENG; SCHROEDER; SHAH, 2008; POWELL, 1995; WATSON; BLACKSTONE; GARDINER, 2007).

This research aimed to analyse the relationships between the use of MCSs and OM techniques and performance by conducting a study on a specific industry and using as a base the competitive advantage combined with the operational capabilities propitiated by operational routines. The diagnostic and interactive uses of MCSs as well as the effects of OM techniques-which primarily involve TQM and continuous improvement practices- 
were analysed in terms of the improvement of performance through cost reduction and new product introduction.

The main contributions of the paper are threefold. The first contribution is related to the nature of the research, which focused on Automotive Components Industry, differently of Oyadomari et al (2011) who have conducted the study in several economy industry. Repetitive studies in different contexts can be a fruitful means of developing a cumulative body of knowledge (MALMI; GRANLUND, 2009). Second, research on MCSs in combination with other disciplines have been suggested to enable integrated analyses to produce different outcomes (ANDERSON, 2007; MALMI; GRANLUND, 2009; NIXON; BURNS, 2012). From such a perspective, this study investigates the effects of MCSs and OM techniques that are used in the same organizational environment. The results of this study are also expected to contribute to the diversity of research to increase the understanding of management practices. Third, this paper also presents practitioners with evidence on how the MCS and OM techniques influence both cost reduction and new product launching, in accordance with the call of Malmi and Granlund (2009) for further studies to provide insights into issues that are of practical interest to the objectives of practitioners. The research confirmed that diagnostic use positively influences cost reduction, with a resulting positive influence on performance. It was also confirmed that interactive use is positively associated with the launching of new products but with less intensity, which suggests that new product launching is influenced by other variables that are not captured in this research. This study also confirmed the research hypothesis by showing that the use of OM techniques is positively associated with cost reduction, but we cautiously note that the use of important tools, such as Six Sigma, remains low.

This article is organised in five sections, including this introduction. In Section 2, the theoretical background for this work is presented. Section 3 includes the methodological aspects, and the results are presented and discussed in Section 4. Final comments are provided in Section 5.

\section{THEORETICAL BACKGROUND}

\subsection{USE OF MCSS AND PERFORMANCE}

Diagnostic control systems - which are used to motivate, monitor and reward the achievement of specific goals - are essential management tools to transform intended strategies into realised strategies (SIMONS, 2000). Through the diagnostic use of an MCS, managers can measure outcomes by comparing them with the planned results and with 
organisational goals. Three features distinguish diagnostic control systems: (i) the ability to measure the outputs of a process, (ii) the existence of predetermined standards against which results can be compared and (iii) the ability to correct deviations from standards (SIMONS, 1995). In addition, this diagnostic use facilitates the monitoring of intended strategies that are not realised; thus, diagnostic use is focused on the traditional role of an MCS, generating feedback information in strategy implementation. Under this situation, diagnostic systems is designed for the sake of efficiency to deliver the value that they are intended to generate (DAVILA, 2005), which is not beneficial for the innovation capability. This point of view suggested by Davila (2005) is in line with concept of exploration and exploitation suggested by researches in business strategy (ADLER et al., 2009; BENNER; TUSHMAN, 2003).

Such diagnostic use comprises the tracking of critical performance variables to monitor and coordinate the intended strategies. The purpose of tracking performance variables is vital once the performance of a company can be improved through alignment of strategies as suggested by Joshi, Kathuria \& Porth (2003). Additionally, the tracking of these performance variables can also provide internal learning to the companies, then it is expected that it can improve internal process and then manifests in operational performance (SCHROEDER; BATES; JUNTTILA, 2002). In manufacturing firms, one competitive priority that is commonly monitored is cost (HAYES; WHEELWRIGHT, 1984; PENG SCHROEDER; SHAH, 2008; WARD et al., 1995). Therefore, it is expected that increased diagnostic use of an MCS will be positively related to cost reduction. Thus, Hypothesis 1 (H1) was established:

H1: There is a positive association between the diagnostic use of MCSs and performance by means of cost reduction.

In competitive industries, innovation through new product development has become one of the critical factors of company strategies (DAVILA, 2000; BROWN; EISENHARDT, 2004; KAPLAN; NORTON, 1996). Firms that do not develop new products assume a higher risk because their products are vulnerable to changes in customer needs and preferences, new technologies, shorter product life-cycles and increased competition (KOTLER, 2000). The introduction of completely new products or services is the easiest identifiable means of innovation, as customers can observe the changes immediately and can expect significant and recurrent technological changes (DAVILA; EPSTEIN; SHELTON, 2007). In addition, the frequent introduction of new products has been one of the most effective means of preventing product imitation. 
Despite patent protection, the work of Kogut and Zander (1992) showed that twothirds of products are imitated by competing firms. For this reason, protection through frequent new production introductions may assist in maintaining a competitive advantage because continuous innovation significantly affects the achievement of superior organisational performance (ROBERTS, 1999; ROBERTS; AMIT, 2003).

Taking the reasoning above, it is crucial for a company to adopt systems or processes that can keep it in continuous innovation. From the firm monitoring perspective, differing from diagnostic systems, interactive control systems provide managers with tools to influence the experimentation and opportunity seeking that may result in emergent strategies (SIMONS, 1995). Interactive controls alert management about strategic uncertainties, problems and opportunities and become the basis for managers to adapt rapidly to environmental changes, leading into new strategies (ANTHONY; GOVINDARAJAN, 2008). Interactive controls exist continually to challenge whether the existing strategies remain appropriate; thus, the interactive use of control systems essentially supports the “devil's advocate" role to ensure that strategies are robust (OTLEY, 2003).

From the operational perspective, the interactive controls supports the exploitation process of the firm, which is vital for both types of innovation (disruptive and continuous). Then, it is reasonable to expect that the organizations that have adopted the interactive controls should present an better performance in new product development than those that have not (ADLER et al., 2009; BENNER; TUSHMAN, 2003). Both Henri (2006a) and Oyadomari et al (2011) confirmed such reasoning showing that interactive use tends to have a positive influence on organisational learning, innovation, entrepreneurship and market orientation. However, the results obtained by Bisbe and Otley (2004) did not confirm the association between greater interactive use and greater product innovation.

The divergence and the scarcity of research mentioned by Davila, Foster and Oyon (2009) indicate that the relationship between the interactive use of an MCS and the innovation process is not obvious. The present research, based on exploration concept and organizational learning (BENNER \& TUSHMAN, 2003, KOGUT AND ZANDER, 1992, HENRI， 2006a),

suggests that there will be a positive association between performance and interactive use. In such a context, Hypothesis 2 (H2) was defined as follows:

H2: There is a positive association between the interactive use of MCSs and organisational performance by means of new product introduction. 


\subsection{OM TECHNIQUES AND PERFORMANCE}

Since the 1980s, practices related to quality improvement have been increasingly implemented (MICHELA; NOORI; JHA, 1996). One of the most well-known practice is total quality management (TQM), which became popular in response to global competition, chiefly in manufacturing firms that confronted strong competition from Japanese firms (ANDERSON; RUNGTUSANATHAM; SCHROEDER, 1994; SCHROEDER; ROBINSON, 1991). In addition to TQM, some OM techniques and tools that have been applied in firms include the following:

Kaizen - Continuous Improvement - Covering suggestion systems and teamwork groups, Kaizen stimulates incremental improvements, with the concept of continuous improvement also being encompassed by other management programmes, including TQM (RECHT; WILDEROM, 1998).

Just in time (JIT) - JIT is a manufacturing programme with the primary goal of continuously reducing and ultimately eliminating all forms of waste. The major forms of waste include the work-in-process inventory and unnecessary delays in the flow of time (CUA; MCKONE; SCHROEDER, 2001).

$5 \mathrm{~S}$ - This participative organisational system for the work environment aims to provide employees with better quality of life, ensure improvements in service quality, promote the better organisation of ideas, and consequently generate higher productivity and cost reduction. $5 \mathrm{~S}$ is derived from the following Japanese words: Seiri (sense of utilisation), Seiton (sense of organisation), Seiso (sense of cleanliness), Seiketsu (sense of health) and Shitsuke (sense of self-discipline) (GAVIOLI; SIQUEIRA; SILVA, 2009).

Six Sigma - This management programme arose at the end of the 1980s at Motorola and can be defined as a systematic and organised method for strategic process improvement and new product and service development that relies on statistical methods and the scientific method aimed at customer satisfaction (PINTO; CARVALHO; HO, 2006; ZU; FREDENDALL; DOUGLAS, 2008).

In the broad literature review by Kaynak (2003), the following TQM practices were identified: top management leadership, training, employee relations, quality data and reporting, supplier quality management, product/service design and process management. In the literature, quality management frameworks normally emphasise the importance of product development by means of multifunctional teams and systematic process management. In 
addition, to ensure that organisations meet or exceed customer expectations, the focus is on involvement of the management, the workforce, suppliers and customers (CUA; MCKONE; SCHROEDER, 2001).

The dissemination of TQM practices and OM techniques occurred presumably because of the main belief that they improve firm performance by means of defect and rework reduction and waste elimination as well as improvements in product and process development and alignment between business and operational strategy (FULLERTON et al., 2003; HENDRICKS et al., 2007, WHEELWRIGHT, 1984). Thus, the reduction of costs is an expected consequence of the implementation of OM techniques (CHENHALL, 1997; HENDRICKS; SINGHAL, 1997; KAYNAK, 2003; POWELL, 1995).

In another study, Chenhall and Langfield-Smith (1998) provided evidence on how the selection of variables related to strategy, management techniques and management accounting practices can combine to affect performance. The authors reported that quality systems provided greater benefits for more successful companies that emphasised product differentiation strategies but not for high-performing companies using low-price strategies. However, the authors observed that companies employing low-price strategies benefitted from quality systems, perhaps because these systems were implemented to minimise waste, thereby decreasing costs. Furthermore, Hendricks and Singhal (1997) provided strong evidence that firms that have won quality awards outperform control firms with respect to operating income-based measures. These authors cited reasonably strong evidence that quality-awarded firms perform better in terms of sales growth and reported weak evidence of the more successful cost control of such firms. Reed, Lemak and Montgomery (1996) argued that for the conditions of a match between environmental uncertainty and firm orientation, market advantages and product reliability can generate revenue growth and process efficiency; in addition, product design efficiency can reduce a firm's costs. Reed, Lemak and Mero (2000) showed that the TQM process has the potential to create sustainable competitive advantages. This opinion is shared by Chenhall (1997), who stated that TQM programmes provide the potential for organisations to improve their profitability by assisting managers in the development of quality as a competitive advantage.

However, there are some criticisms related to TQM practices, such as the significant costs of and barriers to implementation. For example, critics suggest that TQM entails excessive costs associated with retraining; requires an excessive amount of management time; increases paperwork and formalities demanding unrealistic levels of employee commitments; 
emphasises processes rather than results; and fails to address the needs of small firms, service firms and nonprofits (HARARI, 1997; ITTNER; LARCKER, 1997; POWELL, 1995).

The findings of Powell (1995) support the conclusion that TQM can produce economic value for a firm but not necessarily for all TQM adopters. The success of TQM implementation fundamentally depends on the commitment of top management, an organisation's openness and employee empowerment. Furthermore, O’Regan, Sims and Ghobadian (2004) found no correlation between the use of TQM and profitability and actually found that high-achieving companies tend to be less interested in these techniques than those with lower gross profits per employee. In another study, Corredor and Goñi (2011) suggested that the implementation of a TQM system has no significant effect on firm performance. Their evidence showed that only early adopters experience performance gains because of TQM implementation and that the greatest effect on performance occurs a year after receiving external recognition for implementing the system. This research also investigated qualityawarded firms, and the findings contrast with the results of Hendricks and Singhal (1997).

As shown in the previous paragraphs, previous empirical studies have yielded controversial results with regard to the influence of $\mathrm{OM}$ techniques on organisational performance. As can been seen in those previous researches, the controversial results relies on the adoption of the organizational performance, once it is influenced not only by operational capability or techniques, but also by many other variables such as strategic decisions, marketing actions, financial strategies and so on (RAY, BARNEY, \& MUHANNA, 2004). The present study has no ambition to put up an end to this discussion, but we believe that OM techniques, through, its quality philosophies can impact positively in cost reduction, which is an operational performance suggested by Ray, Barney and Muhanna (2004). Under such a context, Hypothesis 3 (H3) was defined:

\section{H3: OM techniques are positively associated with operational performance by} means of cost reduction.

Differentiation strategies require that firms deliver high-quality products and services that satisfy customer needs. As firms frequently seek methods of persuading customers that their products are of high quality, quality management techniques or quality certifications can play a relevant role in firm strategies (CHENHALL; LANGFIELD-SMITH, 1998).

Management techniques, such as TQM and some other OM techniques, comprise not only quality principles but also continuous improvement and organisational learning 
principles that are included in the practices of innovation management (ADLER et al., 2009; BENNER; TUSHMAN, 2002; PRAJOGO; SOHAL, 2001). Teamwork, involvement, employee empowerment and customer focus are characteristics of OM techniques that can create a propitious environment for the innovation process, both for product innovation and for process innovation. In their literature review on the relationship between TQM and innovation, Prajogo and Sohal (2001) concluded that this relationship is complex and ambiguous. There are favourable arguments, as mentioned above, but there are also negative arguments, such as the following: (a) a focus entirely on incremental improvements, (b) the enforcement of standards and formalisation that hinder creativity, (c) a focus on cost efficiency that limits opportunities for innovation and (d) an emphasis on single-loop learning rather than double-loop learning,

The findings of Prajogo and Sohal (2003) suggest that TQM is significantly and positively related to both product quality and product innovation performance. However, its contribution to innovation performance seems inferior to its contribution to quality performance. Therefore, although this result rejected the arguments suggesting that TQM could hinder innovation performance, caution must be exercised before claiming that TQM in its own right is sufficient for achieving high-innovation performance. The findings of those authors indicate a positive and significant relationship between quality performance and innovation performance, particularly process innovation. Furthermore, Perdomo-Ortiz, González-Benito and Galende (2006) presented statistical evidence that suggested a positive relationship between TQM and business innovation capabilities. Their study provides elements of judgement to affirm that the so-called quality practices represent a forerunner to the accumulation of innovation capabilities. Martínez-Costa and Martínez-Lorente (2008) used structural equation modelling (SEM) to show that TQM is an excellent environment for fostering innovation in companies. These authors also provided evidence to support the conclusion that innovation and the implementation of a TQM system yield improvements in company performance. By contrast, Singh and Smith (2004), who also used SEM, concluded that the statistical evidence suggesting that TQM is related to innovation is insufficient. The model presented in their study reflects a linear relationship between TQM constructs and innovation; thus, it is possible that they are related in a more complex manner.

One of the explanations for these controversial results is the contingency perspective of the OM techniques. As suggested by Benner and Tushman (2003), OM techniques that foster efficiency, such as TQM and continuous improvement, will deliver operational performances 
under stable environments and poorer under turbulent conditions. To confirm expectations of contingency perspective, Sousa and Voss $(2001,2008)$ have demonstrated the influences of the plant's manufacturing strategy on the process quality management.

Despite the controversial empirical results, Adler et al (2009) have suggested that the incremental and radical innovation are complementary as well as exploration and exploitation capability. As Farjoun (2010) complemented, exploitation (incremental innovation) enables stability and mechanism for adaptability and exploration (disruptive innovation). Meanwhile, exploration (disruptive innovation) doubts and stimulates discoveries and changes then, challenge the current status quo to innovate and propose better and more reliable processes or mindsets.

Taking the assumption of the complementary perspective of disruptive and incremental innovation (ADLER et al 2009; FARJOUN, 2010), it is expected that OM techniques based on incremental improvements will provide foundations for disruptive innovations. This innovation capability can help an organization to introduce frequently new products into the market as a mean to discourage its imitator (KOGUT; ZANDER, 1992), consequently, retains its competitive advantages temporary (Brown and Eisenhardt, 2004). With this motivation, we established Hypothesis 4 (H4):

H4: There is a positive association between OM techniques and the organisational performance by means of new product introduction.

\section{RESEARCH METHOD}

The primary data were collected through questionnaires. Before the quantitative survey was conducted, a qualitative evaluation was performed to determine the adherence of the researched theme, to evaluate the understanding and validity of the questions in relation to the research objectives and to perform a pre-test with a group of potential respondents. Such a procedure was intended to increase the likelihood that the survey terminology reflects the respondents' frame of reference (VAN DER STEDE; YOUNG; CHEN, 2005).

During the interviews in the qualitative phase, it was noted that the quality programmes could be an important issue for companies in the auto parts industry. New manufacturing plants have been planned by newcomers in the automotive industry in Brazil, which has of course resulted in new opportunities for the auto parts industry. Quality programmes and quality certifications tend to be among the requirements for new businesses. 
Following Van der Stede, Young and Chen (2005), this research specifies the target population as the managers of firms and business units, and the survey population is the managers of firms that are associated with Sindipeças (National Union for the Automotive Components Industry). Sindipeças encompasses approximately 500 associates comprising small, medium and large companies in the auto parts industry.

Initially, a presentation letter was sent to 512 Sindipeças associates by e-mail. Subsequently, phone calls were also made based on the phone list provided by Sindipeças. Among the 101 questionnaires returned, 98 were validated to serve as the research base, which resulted in a response rate of $19 \%$.

\subsection{MEASUREMENT INSTRUMENTS}

In this study, cost reduction was used as an indicator of operational performance. For innovation competence, the adopted indicator was new product introduction.

The questions related to the constructs of diagnostic use (four questions) and interactive use (seven questions) were fully translated from the work of Henri (2006a). The variables for the performance construct (six indicators) were adapted from the studies of Bisbe and Otley (2004) and Govindarajan (1984). The construct OM techniques (five indicators) includes the practices that were mentioned by the interviewees during the first phase of the research in accordance with the main literature.

A Likert scale was adopted because of its advantage of providing several statements in a list of objective answers with little space and its simplicity for respondents (COLLINS; HUSSEY, 2005). A seven-point scale was adopted for most of the questionnaire. The questionnaire items are shown in Appendix.

\subsection{DATA ANALYSIS}

The hypotheses of relationships established in this research were tested through SEM, which is a multivariate analysis technique that is used to explain relationships of multiple and interrelated dependency by combining aspects of factor analysis and multiple regression analysis (HAIR JR. et al., 2009).

Smith and Langfield-Smith (2004) suggested that SEM could be used in management accounting research to analyse the effects of relationships among environment, strategy, structure and control systems on organisational effectiveness, which is precisely the aim of this research. Furthermore, the use of SEM has been increasing in the accounting empirical 
research (CADEZ; GUILDING, 2008; CHENHALL, 2005; HENRI, 2006a; NARANJO-GIL; HARTMANN, 2007).

We used the software SmartPLS 2.0 (RINGLE; WENDE; WILL, 2005), which utilises the PLS method. This method can be applied for small samples and can also accommodate non-normal data (SMITH; LANGFIELD-SMITH, 2004). For more detailed information and example of PLS and SmartPLS, we recommend the following readings: Ringle, Silva and Bido (2014) and Hair, Hult and Ringle (2014).

\section{RESULTS}

\subsection{MEASUREMENT MODEL}

Initially, a test for convergent validity was performed (Table 1). Because all but two of the variables presented loadings exceeding 0.6 and the two that did not were close to 0.60 , we chose not to exclude any variables. All of the constructs presented average variance extracted (AVE) values above 0.50 (Table 1). The rate of composite reliability and the Cronbach's alphas exceeded the cutoff value of 0.70 (HAIR JR. et al., 2009).

Table 1 - Reliability and Model Validity

\begin{tabular}{l|r|r|r|r}
\hline & AVE & $\begin{array}{c}\text { Composite } \\
\text { Reliability }\end{array}$ & R Square & $\begin{array}{c}\text { Cronbach's } \\
\text { Alpha }\end{array}$ \\
\hline Performance (PERF) & 0.573 & 0.888 & 0.465 & 0.847 \\
\hline New Product Introduction (NPROD) & 1.000 & 1.000 & 0.055 & 1.000 \\
\hline Cost Reduction (COST) & 1.000 & 1.000 & 0.180 & 1.000 \\
\hline Management Techniques (MTEC) & 0.542 & 0.853 & - & 0.826 \\
\hline Diagnostic Use (DIAG) & 0.789 & 0.937 & - & 0.911 \\
\hline Interactive Use (INTER) & 0.787 & 0.963 & - & 0.955 \\
\hline
\end{tabular}

The discriminant validity is confirmed in Table 2. The diagonal in bold contains the square roots of the average extracted variances (AVE). All of the correlations are lower than the amounts of the square roots of the AVE, indicating that the constructs are correlated but distinct. 
Table 2 - Correlation Matrix

\begin{tabular}{l|c|c|c|c|c|c}
\hline & PERF & NPROD & COST & MTEC & DIAG & $\begin{array}{c}\text { INTE } \\
\text { R }\end{array}$ \\
\hline Performance (PERF) & $\mathbf{0 . 7 5 7}$ & - & - & - & - & - \\
\hline $\begin{array}{l}\text { New Product Introduction } \\
\text { (NPROD) }\end{array}$ & 0.505 & $\mathbf{1 . 0 0 0}$ & - & - & - & - \\
\hline Cost Reduction (COST) & 0.627 & 0.416 & $\mathbf{1 . 0 0 0}$ & - & - & - \\
\hline Management Techniques (MTEC) & 0.367 & 0.145 & 0.363 & $\mathbf{0 . 7 3 6}$ & - & - \\
\hline Diagnostic Use (DIAG) & 0.366 & 0.254 & 0.373 & 0.511 & $\mathbf{0 . 8 8 8}$ & - \\
\hline Interactive Use (INTER) & 0.393 & 0.233 & 0.383 & 0.552 & 0.792 & $\mathbf{0 . 8 8 7}$ \\
\hline
\end{tabular}

\subsection{STRUCTURAL MODEL}

Table 3 shows the regression coefficients and the t-values, and Figure 1 displays the relationship diagram showing the t-values (the values are below the arrows that link the variables or constructs).

Table 3 - Path Coefficients

\begin{tabular}{l|r|r|r|c}
\hline & Original & $\begin{array}{c}\text { Standard } \\
\text { Error } \\
\text { Sample (O) } \\
\text { (STERR) }\end{array}$ & $\begin{array}{c}\text { T-Statistics } \\
(\mid \mathbf{O} / \text { STERR } \mid)\end{array}$ & p-value \\
\hline New Product Introduction (NPROD) -> Performance & 0.296 & 0.077 & 3.854 & 0.0001 \\
\hline Cost Reduction (COST) -> Performance (PERF) & 0.504 & 0.070 & 7.204 & 0.0000 \\
\hline Management Techniques (MTEC) -> NPROD & 0.024 & 0.089 & 0.275 & 0.7834 \\
\hline Management Techniques (MTEC) -> COST & 0.233 & 0.097 & 2.404 & 0.0164 \\
\hline Diagnostic Use (DIAG) -> COST & 0.254 & 0.094 & 2.690 & 0.0073 \\
\hline Interactive Use (INTER) -> NPROD & 0.219 & 0.108 & 2.034 & 0.0001 \\
\hline
\end{tabular}




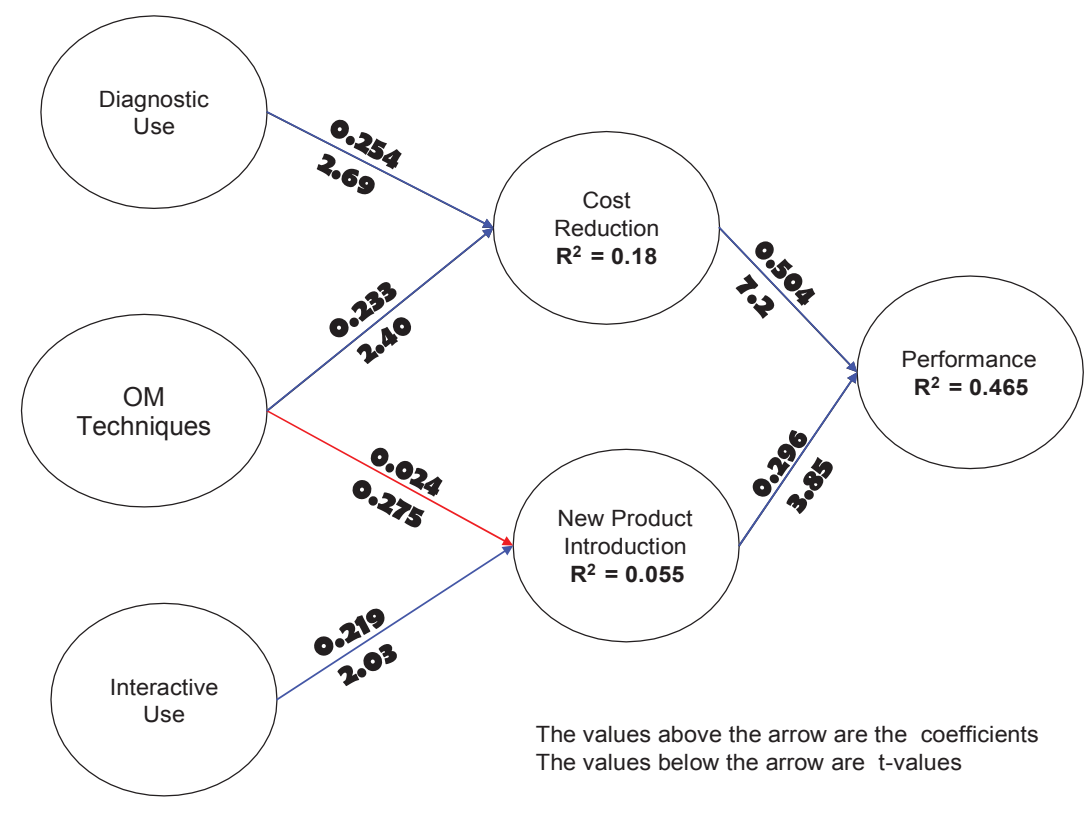

Figure 1: PLS Model

All of the relationships were considered significantly positive with a level of significance of 0.05 , except for the relationship between management techniques and new product introduction, for which no statistical significance was identified.

\subsection{DISCUSSION}

H1, which proposes the relationship between the diagnostic use of MCSs and the reduction of costs, was supported. Regardless of the level of development of a firm's MCS or of the specific information system used by managers, such diagnostic use has the traditional function of a feedback system (SIMONS, 2000), such that managers can evaluate the results from their actions in their firm's operations. This diagnostic use allows for the monitoring and accomplishment of the critical performance variables by ensuring an explicit top-down linkage of intended strategies to lower-level goals and the coordination of resources and action plans as well as by providing benchmarks for corrective actions (SIMONS, 1995).

The operational costs of a firm typically constitute one of the main performance variables, notably in the competitive auto parts industry; thus, cost reduction projects are recurrent in firms. In the area of operations, for instance, among the competitive priorities, it is common to emphasise competence in cost reduction (FULLERTON; MCWATTERS; FAWSON, 2003; HAYES; WHEELWRIGHT, 1984; SCHROEDER; BATES; JUNTTILA, 2002; WARD et al., 1995). 
The association between diagnostic use and cost reduction is consistent with the perception of the culture of control within the auto parts industry. The firms in this industry have large carmakers as references that exert price pressure on the entire supply chain. The heavy competition and targets that are imposed by carmakers require constant operations monitoring.

The control values refer to predictability, stability, formality, rigidity and conformity (HENRI, 2006b; AGBEJULE, 2011). Firms under the predominance of a control culture are oriented towards efficiency and tend to promote tight control of their operations. Thus, it is natural that auto parts firms use the MCS with a diagnostic focus to search for means of cost reduction, as confirmed in this research.

Additionally, the diagnostic uses of MCS enhance the strategic alignment between business and operational strategy, which manifest in cost reduction. This result supports prior study of Joshi, Kathuria, \& Porth (2003) where strategic alignment was investigated and not necessary well practiced by all the companies.

H2, which proposes the relationship between the interactive use of MCSs and new product introduction, was supported at a 0.05 level of significance. This result also indicates that interactive use can be potentially improved to ensure that greater benefits can be produced in the innovation process. Interactive use stimulates the pursuit of opportunities and encourages the emergence of new strategic initiatives (SIMONS, 1995). Strategic uncertainties constantly threaten the intended strategies of firms, invalidating previous assumptions; thus, interactive use allows the emerging of new strategies through the dialogue, debate and learning that surround the interactive process (SIMONS, 1995). The uncertainties of a strategic nature refer to fundamental changes in different environments that can potentially break the rules under which an organisation is operating (ANTHONY; GOVINDARAJAN, 2008). Changes in consumer preferences, technologies in constant evolution and substitute products are examples of threats or opportunities of which the interactive use of an MCS can provide full awareness to enable the reevaluation of a firm's strategy. Under this scenario, innovation through new products has become a relevant factor in the strategies of firms.

According to Toledo et al. (2008) in their research of the Brazilian auto parts industry, $70 \%$ of firms cited the trend of a growing number of new product introductions. In addition, the introduction of new products with lower and lower costs is frequently a mandatory condition. In the auto parts industry, such a situation is typical. For this reason, the results of 
this research, which offers evidence that firms use MCSs interactively and that there is a positive relationship with new product introductions, are particularly important for the auto parts industry.

The validation of this hypothesis of association between the interactive use of MCSs and the innovation process through new product introductions is consistent with the work of Henri (2006a), who demonstrated the influence of interactive use on organisational capabilities, including innovation.

To reinforce the discussion, as the interactive use of MCSs support challenging mindsets and learning philosophies, it enables the development of exploration capability of the organization, which manifest in the new product introduction into the market (BENNER \& TUSHMAN, 2003).

In the current study, $\mathbf{H 3}$ was also supported because the statistical data analyses indicated that there is a positive relationship between the use of OM techniques and cost reduction. The OM practices that were analysed refer to the concepts of quality programmes whose main model is the TQM. TQM comprises a series of practices that emphasises continuous improvement, the fulfilment of customer requirements, teamwork and employee involvement, competitive benchmarking, team-based problem solving and closer relationships with suppliers (POWELL, 1995). These basic assumptions target the sustainability of the quality of products and processes, the increased satisfaction of clients and employees, lower costs and improvements in organisational performance.

Some of the activities involved in these practices are directly linked to efficiency improvement and cost reduction. For example, the elimination of waste and continuous improvement in processes with reduced waiting time between production phases tend to reduce production costs. Other activities, such as multifunctional teamwork and training, may indirectly promote cost reduction (KAYNAK, 2003).

In the auto parts industry, such management practices have been propitiated and, in many cases, required by customers, primarily carmakers. The requirements for quality certifications stimulate the adoption of management practices directed towards quality programmes. However, the implementation of these techniques can be conducted either in a comprehensive and planned manner or in a partial and limited arrangement aimed at only certain certifications. The evidence from this research shows that the utilisation of these techniques in the auto parts industry still presents relative variability, indicating that the 
utilisation rate remains reasonably variable or that the implementation stages of the programmes differ between firms.

The results of this research suggest that the adoption of management techniques in firms under the predominance of a control culture has positively influenced such firms in their objective of cost reduction. This finding suggests that even under circumstances of partial utilisation or implementation, these management techniques can favourably influence cost reduction projects. The average utilisation rates are not high, indicating that there is potential for improvement in the firms, especially in relation to Six Sigma and TQM.

Our findings also reinforce and support the contingency aspect of the relationship between OM techniques and organizational performance (Sousa \& Voss, 2001; 2008).

H4 was not supported, indicating that the association between management practices and new product introduction is not statistically significant. The principles that characterise OM practices such as TQM, including customer focus, employee participation and involvement, top management commitment, relationship with suppliers and continuous improvement processes, are arguments that are favourable to innovation capabilities (PERDOMO-ORTIZ; GONZÁLEZ-BENITO; GALENDE, 2006). However, the results of this research do not support this reasoning in relation to new product introduction.

Furthermore, factors such as process standardisation and formalities in the internal procedures that are perceived as negatively influencing the innovation process (HARARI, 1997) may counteract the favourable aspects in the process of new product introduction.

Another possible explanation is related to the benefits of these management practices, which can occasionally emerge in other aspects of the innovation process. In some firms, innovation efforts can be focused on improvements related to cost effectiveness. Thus, quality systems may have been implemented to minimise waste and primarily developed to identify cost reduction efforts (CHENHALL; LANGFIELD-SMITH, 1998). This contention is coherent with the reality of the Brazilian auto parts industry, in which the main challenges include global competition as well as price and cost pressures (ROLLI, 2011).

The heterogeneous organisational features in the auto parts industry in Brazil may have also contributed to these results. Organisational characteristics, such as firm size, intensive capital utilisation, TQM adoption time and management techniques maturity, may moderate the benefits derived from TQM (HENDRICKS; SINGHAL, 2000). The characteristics of the auto parts industry may also interfere in the relationship between management practices and 
product innovation because many projects developed in firms are actually projects that are developed by the headquarters of multinational subsidiaries or by their customers (TOLEDO et al., 2008).

Kaynak (2003) also indicated that partial TQM implementation can justify the failure to receive the full benefits, as several TQM practices are interrelated. For instance, the commitment of top management has a significant role in successful TQM implementation, which significantly affects other TQM activities. Thus, without adequate management commitment, the potential benefits of TQM can be impaired.

The research data indicate that the average rates of utilisation, primarily TQM and Six Sigma, are relatively low; therefore, the results suggest that the utilisation level is not sufficient to influence the process of new product introduction. Thus, these results suggest opportunities for researchers to conduct further studies in an attempt to understand the complex relationship between management techniques and innovation processes. For example, such research could involve other variables and other relationship structures. Furthermore, the results of the current study also suggest possible areas of improvement in the innovation process through the use of OM techniques.

The implementation of management techniques strictly to obtain quality certification may induce firms to focus only on the minimum requirements for certification, without the effective acculturation and utilisation of management techniques. In such a scenario, the potential benefits are only partial or incomplete.

\section{FINAL COMMENTS}

This study aimed to demonstrate the effects of the use of MCSs and OM techniques on organisational performance through cost reduction and new product introduction. This industry-focused research was performed in the auto parts industry by means of a survey with the associated firms of the Brazilian National Union for the Automotive Components Industry (Sindipeças).

The research provided statistical support for three of the four research hypotheses. The relationships of the uses of MCSs were supported. In the Brazilian auto parts industry, the diagnostic use of MCSs is positively associated with the goal of cost reduction, and the interactive use is positively associated with the objectives of new product introduction. In relation to the use of the OM techniques, this research confirmed that TQM positively 
influences the goals of cost reduction; however, the hypothesis of a positive association with the objectives of new product introduction was not statistically supported.

The results should be interpreted by considering the limitations of examining the perceptions of the managers of the firms in the sample, as their views may differ from the perceptions of other managers. In addition, the sample was non-probabilistic; therefore, the results cannot be generalised. Furthermore, as the modelling of any context simplifies reality, other variables that were omitted from the model may have had an influence on the analysed relationships.

With regard to business management, this research provides evidence of the importance of the use of MCS in a firm's strategic priorities. It should be emphasised that the diagnostic use of MCSs contributes to cost reduction plans and that the interactive use of MCSs may exert significant influence on innovation processes involving new product introduction. The adoption of management techniques is also a factor contributing to cost reduction, although there is no apparent benefit in the new product introduction process, which may be an industry characteristic or may result from the specific sample, which included a relevant portion of small and medium firms with low rates of TQM and Six Sigma implementation.

In addition to examining possible mediators or moderators in the relationships of the use of MCSs and management techniques to improve organisational performance, future researchers should consider contingent factors that may interfere with these relationships as well as more qualitative studies.

\section{REFERENCES}

ADLER, P. S. et al. Perspectives on the productivity dilemma. Journal of Operations Management, v. 27, p. 99-113, 2009.

AGBEJULE, A. Organizational culture and performance: the role of management accounting system. Journal of Applied Accounting Research, v.12, n.1, p.74-89, 2011.

ANDERSON, S.W. Managing costs and cost structure throughout the value chain: research on strategic cost management. In: CHAPMAN, C. S.; HOPWOOD, A. G.; SHIELDS, M. D. (Eds.). Handbook of management accounting research. Oxford: Elsevier, 2007. v. 2. p.451-506.

ANDERSON, J. C.; RUNGTUSANATHAM , M.; SCHROEDER, R. G. A theory of quality management underlying the deming management method. The Academy of Management Review, v.19, n.3, p.472-509, 1994.

ANTHONY, R. N.; GOVINDARAJAN, V. Sistemas de controle gerencial. 12. ed. São Paulo: McGraw-Hill, 2008. 
BENNER, M. J.; TUSHMAN, M. Process management and technological innovation: a longitudinal study of the photography and paint industries. Administrative Science Quarterly, v. 47, n. 4, p. 676-706, 2002.

BENNER, M. J.; TUSHMAN, M. Exploitation, exploration and process management: the productivity dilemma revisited. Academy of Management Review, v. 28, n. 2, 2003.

BISBE, J.; OTLEY, D. The effects of the interactive use of management control systems on product innovation. Accounting, Organizations and Society, v. 29, p. 709-737, 2004.

BROWN, S. L.; EISENHARDT, K. M. Estratégia competitiva no limiar do caos: uma visão dinâmica para as transformações corporativas. São Paulo: Cultrix, 2004.

CADEZ, S.; GUILDING, C. An exploratory investigation of an integrated contingency model of strategic management accounting. Accounting, Organizations and Society, v. 33, p. 836-863, 2008.

CHENHALL, R. H. Reliance on manufacturing performance measures, total quality management and organizational performance. Management Accounting Research, v. 8, p. 187-206, 1997.

Integrative strategic performance measurement systems, strategic alignment of manufacturing, learning and strategic outcomes: an exploratory study. Accounting, Organizations and Society, v. 30, p. 395-422, 2005.

CHENHALL, R. H.; LANGFIELD-SMITH, K. The relationship between strategic priorities, management techniques and management accounting: an empirical investigation using a systems approach. Accounting, Organizations and Society, v. 23, n. 3, p. 243-264, 1998.

.;. Multiple perspectives of performance measures. European Management

Journal, v.25, n.4, p.266-282, 2007.

COLLIS, J.; HUSSEY, R. Pesquisa em administração: um guia prático para alunos de graduação e pós-graduação. 2. ed. Porto Alegre: Bookman, 2005.

CORREDOR, P.; GONI, S. TQM and performance: Is the relationship so obvious? Journal of Business Research, v. 64, p. 830-838, 2011.

CUA, K. O.; MCKONE, K. E.; SCHROEDER, R. G. Relationships between implementation of TQM, JIT, and TPM and manufacturing performance. Journal of Operations Management, v. 19, p. 675-694, 2001.

DAVILA, A.; FOSTER, G.; OYON, D. Accounting and control, entrepreneurship and innovation: venturing into new research opportunities. European Accounting Review, v. 18, n. 2, p. 281-311, 2009.

DAVILA, T. An empirical study on the drivers of management control systems' design in new product development. Accounting, Organizations and Society, v. 25, n. 4, p. 383-409, 2000 . 
The promise of management control systems for innovation and strategic change. In: CHAPMAN, C.S. (Ed.). Controlling strategy: management, accounting, and performance measurement. Oxford: Oxford University Press, 2005. p. 37-61.

DAVILA, T.; EPSTEIN, M. J.; SHELTON, R. As regras da inovação: como gerenciar, como medir e como lucrar. Porto Alegre: Bookman, 2007.

DIMAGGIO, P. J.; POWELL, W. W. The iron cage revisited: institutional isomorphism and collective rationality in organizational fields. American Sociological Review, v. 48, n. 2, p. 147-160, 1983.

FARJOUN, M. Beyond dualism: stability and change as a duality. Academy of Management Review, v. 35, n. 2, p. 202-225, 2010

FERDOWS, K.; DE MEYER, A. Lasting improvements in manufacturing: in search of a new theory. Journal of Operations Management, v. 9, n. 2, p. 168-184, 1990.

FERREIRA, A.; OTLEY, D. Exploring inter and intra-relationships between the design and use of management control systems. Working Paper Series, Social Science Research Network, 2006.

FULLERTON, R. R.; MCWATTERS, C. S.; FAWSON, C. An examination of the relationships between JIT and financial performance. Journal of Operations Management, v. 21, p. 383-404, 2003.

FLYNN, B. B.; FLYNN, E. J. An exploratory study of the nature of cumulative capabilities. Journal of Operations Management, v. 22, p. 439-457, 2004.

GAVIOLI, G.; SIQUEIRA, M. C. M.; SILVA, P. H. R. Aplicação do programa 5S em um sistema de gestão de estoques de uma indústria de eletrodomésticos e seus impactos na racionalização de recursos. In: SIMPÓSIO DE ADMINISTRAÇÃO DA PRODUÇÃO, LOGÍSTICA E OPERAÇÕES INTERNACIONAIS (SIMPOI), 13., 2009. São Paulo (SP). Anais... São Paulo: FGV-EAESP, 2009.

GOVINDARAJAN, V. Appropriateness of accounting data in performance evaluation: an empirical examination of environmental uncertainty as an intervening variable. Accounting, Organizations and Society, v. 9, n. 2, p. 125-135, 1984.

HAIR JR., J. F. et al. Análise multivariada de dados. 6. ed. Porto Alegre: Bookman, 2009.

HAIR JR, J. F.; HULT, G. T. M.; RINGLE, C. A primer on partial least squares structural equation modeling (PLS-SEM). Chicago: Sage Publications, 2014.

HARARI, O. Ten reasons TQM doesn't work. Management Review, v. 86, n. 1, p. 38-44, 1997.

HAYES, R. H.; WHEELWRIGHT, S. C. Restoring our competitive edge: competing through manufacturing. New York: John Wiley \& Sons, 1984.

HENDRICKS, K. B.; SINGHAL, V. R. Does implementing an effective tqm program actually improve operating performance? Empirical evidence from firms that have won quality awards. Management Science, v. 43, n. 9, p. 1258-1274, 1997. 
HENDRICKS, K. B.; SINGHAL, V. R. Firm characteristics, total quality management, and financial performance. Journal of Operations Management, v. 238, p. 1-17, 2000.

HENDRICKS, K. B.; SINGHAL, V. R.; STRATMAN, J. K. The impact of enterprise systems on corporate performance: a study of ERP, SCM, and CRM system implementations. Journal of Operations Management, v. 25, n. 1, p. 65-82, 2007.

HENRI, J.-F. Management control systems and strategy: a resource-based perspective. Accounting, Organizations and Society, v. 31, p. 529-558, 2006a.

HENRI, J.-F. Organizational culture and performance measurement systems. Accounting, Organizations and Society, v. 31, p. 77-103, 2006 b.

ITTNER, C. D.; LARCKER, D. F. Quality strategy, strategic control systems, and organizational performance. Accounting, Organizations and Society, v. 22, n. 3/4, p. 293 314, 1997.

JOSHI, M. P.; KATHURIA, R.; PORTH, S. J. Alignment of strategic priorities and performance: an integration of operations and strategic management perspectives. Journal of Operations Management, v. 21, n. 3, p. 353-369, 2003.

KAPLAN, R. S.; NORTON, D. P. The balanced scorecard: translating strategy into action. Boston, MA: Harvard Business School Press, 1996.

.;. Mapas estratégicos: balanced scorecard: convertendo ativos intangíveis em resultados tangíveis. Rio de Janeiro: Elsevier, 2004.

KAYNAK, H. The relationship between total quality management practices and their effects on firm performance. Journal of Operations Management, v. 21, p. 405-435, 2003.

KOGUT, B.; ZANDER, U. Knowledge of the firm, combinative capabilities, and the replication of technology. Organization Science, v. 3, n. 3, p. 383-397, 1992.

KOTLER, P. Administração de marketing. 10. ed. São Paulo: Prentice Hall, 2000.

MALMI, T.; GRANLUND, M. In search of management accounting theory. European Accounting Review, v. 18, n. 3, p. 597-620, 2009.

MARTÍNEZ-COSTA, M.; MARTÍNEZ-LORENTE, A. R. Does quality management foster or hinder innovation? An empirical study of Spanish companies. Total Quality Management, v. 19, n. 3, p. 209-221, 2008.

MICHELA, J. L.; NOORI, H.; JHA, S. The dynamics of continuous improvement. International Journal of Quality Science, v. 1, n. 1, p. 19-47, 1996.

NARANJO-GIL, D.; HARTMANN, F. Management accounting systems, top management team heterogeneity and strategic change. Accounting, Organizations \& Society, v. 32, p. 735-756, 2007.

NIXON, B.; BURNS, J. The paradox of strategic management accounting. Management Accounting Research, v. 23, p. 229-244, 2012. 
O'REGAN, N.; SIMS, M.; GHOBADIAN, A. The impact of management techniques on performances in technology-based firms. Technovation, v. 24, p. 265-273, 2004.

OTLEY, D. Management control and performance management: whence and whither? The British Accounting Review, v. 35, p. 309-326, 2003.

OYADOMARI, J. C. T. et al. Uso do sistema de controle gerencial e desempenho: um estudo em empresas brasileiras sob a perspectiva da resources-based view. REAd - Revista Eletrônica de Administração, v. 69, n. 2, p. 298-329, 2011.

PENG, D. X.; SCHROEDER, R.G.; SHAH, R. Linking routines to operations capabilities: a new perspective. Journal of Operations Management, v. 26, p. 730-748, 2008.

PERDOMO-ORTIZ, J.; GONZÁLEZ-BENITO, J.; GALENDE, J. Total quality management as a forerunner of business innovation capability. Technovation, v. 26, p. 1170-1185, 2006.

PINTO, S. H. B.; CARVALHO, M. M.; HO, L.L. Implementação de programas de qualidade: um survey em empresas de grande porte no Brasil. Gestão \& Produção, v. 13, n. 2, p. 191203, 2006.

POWELL, T. C. Total quality management as competitive advantage: a review and empirical study. Strategic Management Journal, v. 16, p. 15-37, 1995.

PRAJOGO, D. I.; SOHAL, A. S. TQM and innovation: a literature review and research framework. Technovation, v. 21, p. 539-558, 2001.

PRAJOGO, D. I.; SOHAL, A. S. The relationship between TQM practices, quality performance, and innovation performance: an empirical examination. International Journal of Quality \& Reliability Management, v. 20, n. 8, p. 901-918, 2003.

RAY, G.; BARNEY, J. B.; MUHANNA, W. A. Capabilities, business processes, and competitive advantage: choosing the dependent variable in empirical tests of the resource-based view. Strategic Management Journal, v. 25, n. 1, p. 23-37, 2004.

RECHT, R.; WILDEROM, C. Kaizen and culture: on the transferability of Japanese suggestion systems. International Business Review, v.7, p.7-22, 1998.

REED, R.; LEMAK, D. J.; MERO, N. P. Total quality management and sustainable competitive advantage. Journal of Quality Management, v. 5, p. 5-26, 2000.

REED, R.; LEMAK, D.; MONTGOMERY, J. C. TQM content and firm performance. Academy of Management, v. 21, n. 1, p. 173-202, 1996.

RINGLE, C. M.; DA SILVA, D.; BIDO, D. S. Modelagem de equações estruturais com utilização do smartpls. Revista Brasileira de Marketing, v. 13, n. 2, p. 56-73, 2014.

RINGLE, C. M.; WENDE, S.; WILL, A. SmartPLS 2.0 (beta). Germany: University of Hamburg, 2005. Disponível em: <http://www.smartpls.de>. Acesso em: 24 set. 2010.

ROBERTS, P. W. Product innovation, product-market competition and persistent profitability in the U.S. pharmaceutical industry. Strategic Management Journal, v. 20, p. 655-670, 1999. 
ROBERTS, P. W.; AMIT, R. The dynamics of innovative activity and competitive advantage: the case of Australian retail banking: 1981 to 1995. Organization Science, v. 14, n. 2, p. 107-122, 2003.

ROLLI, C. Setor de autopeças deve fechar o ano com déficit recorde. Folha de São Paulo, São Paulo, 11 abril 2011. Disponível em: <www.folha.com.br>. Acesso em: 27 nov. 2011.

SCHROEDER, R. G.; BATES, K. A.; JUNTTILA, M. A resource-based view of manufacturing strategy and the relationship to manufacturing performance. Strategic Management Journal, v. 23, n. 2, p. 105-117, 2002.

SCHROEDER, D. M.; ROBINSON, A.G. America's most successful export to japan: continuous improvement programs. Sloan Management Review, v. 32, n. 3, p. 67-81, 1991.

SIMONS, R. Levers of control: how managers use innovative control systems to drive strategic renewal. Boston: Harvard Business School Press, 1995.

. Performance measurement \& control systems for implementing strategy. Upper Saddle River: Prentice-Hall, 2000.

SINGH, P. J.; SMITH, A. J. R. Relationship between TQM and innovation: an empirical study. Journal of Manufacturing Technology Management, v. 15, n. 5, p. 394-401, 2004.

SKINNER, W. Manufacturing-missing link in corporate strategy. Harvard Business Review, v. 11, maio/jun. 1969.

SMITH, D.; LANGFIELD-SMITH, K. Structural equation modeling in management accounting research: critical analysis and opportunities. Journal of Accounting Literature, v. 23, p. 49-86, 2004.

SOUSA, R.; VOSS, C. A. Quality management: universal or context dependent? Production and Operations Management, v. 10, n. 4, p. 383-404, 2001.

SOUSA, R.; VOSS, C. A. Contingency research in operations management practices. Journal of Operations Management, v. 26, n. 6, p. 697-713, 2008.

TOLEDO, J. C. et al. Práticas de gestão no desenvolvimento de produtos em empresas de autopeças. Produção, v.18, n. 2, p. 405-422, 2008.

VAN DER STEDE, W. A.; YOUNG, S. M.; CHEN, C.X. Assessing the quality of evidence in empirical management accounting research: the case of survey studies. Accounting, Organizations and Society, v. 30, p. 655-684, 2005.

WATSON, K. J.; BLACKSTONE, J. H.; GARDINER, S. C. The evolution of a management philosophy: the theory of constraints. Journal of Operations Management, v. 25, n. 2, p. $387-402,2007$.

WARD, P. T. et al. Business environment, operations strategy, and performance: an empirical study of Singapore manufacturers. Journal of Operations Management, v. 13, p. 99-115, 1995. 
WHEELWRIGHT, S. Manufacturing strategy: defining the missing link. Strategic Management Journal, v. 5, n. 1, p. 77-91, 1984.

WHEELWRIGHT, S.; HAYES, R. Competing through manufacturing stages of manufacturing. Harvard Business Review, v. 63, n. 1, p. 99-110, 1985.

WIDENER, S. K. An empirical analysis of the levers of control framework. Accounting, Organizations and Society, v. 32, n. 7-8, p. 757-788, 2007.

ZU, X.; FREDENDALL, L. D.; DOUGLAS, T. J. The evolving theory of quality management: the role of Six Sigma. Journal of Operations Management, v. 26, p. 630-650, 2008 .

\section{APPENDIX - QUESTIONNAIRE ITEMS}

Rate the extent to which the top management and management team use management control tools to perform the activities below ( 1 = never used; 7 = very frequently used).

\begin{tabular}{|c|c|c|c|}
\hline & Mean & $\begin{array}{l}\text { Standard } \\
\text { Deviation }\end{array}$ & Loadings \\
\hline \multicolumn{4}{|l|}{ DIAGNOSTIC USE } \\
\hline Track progress towards goals & 5.93 & 1.06 & 0.8571 \\
\hline Monitor results & 6.04 & 1.08 & 0.9165 \\
\hline Compare outcomes with expectations & 5.92 & 1.07 & 0.8956 \\
\hline Review key measures & 5.63 & 1.24 & 0.8825 \\
\hline \multicolumn{4}{|l|}{ INTERACTIVE USE } \\
\hline $\begin{array}{l}\text { Enable discussion in meetings with superiors, } \\
\text { subordinates and peers }\end{array}$ & 5.59 & 1.43 & 0.8220 \\
\hline $\begin{array}{l}\text { Enable continual challenge and debate underlying data, } \\
\text { assumptions and action plans }\end{array}$ & 5.29 & 1.38 & 0.8621 \\
\hline Provide a common view of the organisation & 5.39 & 1.27 & 0.9056 \\
\hline Tie the organisation together & 5.53 & 1.21 & 0.9172 \\
\hline Enable the organisation to focus on common issues & 5.43 & 1.19 & 0.8632 \\
\hline $\begin{array}{l}\text { Enable the organisation to focus on critical success } \\
\text { factors }\end{array}$ & 5.46 & 1.19 & 0.9383 \\
\hline Develop a common vocabulary in the organisation & 5.29 & 1.23 & 0.8967 \\
\hline
\end{tabular}


For each of the following indicators, rate the extent to which the results of the company are well below (1) to well above (7) the expected outcomes.

\begin{tabular}{l|l|l|l}
\hline NEW PRODUCT INTRODUCTION & Mean & $\begin{array}{l}\text { Standard } \\
\text { Deviation }\end{array}$ & Loadings \\
\hline COST REDUCTION & 4.80 & 1.22 & \\
\hline PERFORMANCE & 4.84 & 1.22 & \\
\hline Sales growth & & & \\
\hline Return on investments & 5.28 & 1.13 & 0.7582 \\
\hline Profit margin & 4.86 & 1.28 & 0.8446 \\
\hline Customer satisfaction & 4.50 & 1.33 & 0.8079 \\
\hline Market share & & & \\
\hline Global performance & 5.56 & 0.94 & 0.5577 \\
\hline
\end{tabular}

For the programmes below, rate the extent to which each of them is used in your company $(1$ = very little; 7 = very much); indicate N/A if an item is not applicable in your company.

\begin{tabular}{l|c|c|c}
\hline & Mean & $\begin{array}{c}\text { Standard } \\
\text { Deviation }\end{array}$ & Loadings \\
\hline MANAGEMENT TECHNIQUES & & & \\
\hline Six Sigma & 2.45 & 2.56 & 0.5929 \\
\hline 5S & 4.47 & 2.31 & 0.6916 \\
\hline TQM & 3.81 & 2.57 & 0.6745 \\
\hline Kaizen (Continuous Improvement Programme) & 4.33 & 2.38 & 0.797 \\
\hline Suggestion Programme & & & 0.8873 \\
\hline
\end{tabular}

